\title{
Tracing innovation pathways in the management of natural and social capital on Laikipia Maasai Group Ranches, Kenya
}

\author{
Staline Kibet ${ }^{1 *}$, Moses Nyangito ${ }^{1}$, Laban MacOpiyo ${ }^{1}$ and David Kenfack ${ }^{2}$
}

\begin{abstract}
Group ranches (GRs) were established in Kenya in the 1960s and 1970s; their objectives included the increase of pastoral land productivity and the control of land degradation. Since their establishment, GRs have evolved and new trends have emerged in resource management with significant impact on socio-ecological systems (SESs). Little is known about these changes on the GRs in Laikipia County. The central thesis for this study was that GRlevel-driven and/or collective action innovations are socio-ecologically more resilient compared to household/ individual-level strategies. This study investigated emerging innovations, their drivers and perceived and felt impacts, using II Motiok GR as a case study. Tools used included semi-structured interviews, key informant interviews, focus group discussions and second order cybernetics. Qualitative analysis using SPSS software was done. The results showed that emerging innovations could be divided into either household/individual- or community-level-driven processes. Some of the innovations in natural capital management included the trading of grazing rights, expansion of traditional enclosures, adoption of 'new' livestock species and/or breeds, and crop cultivation. Household-level-driven innovations were influenced by wealth status, age and level of education. Economic returns and to some extent the greater good influenced community-driven initiatives. Formal groupings such as self-help groups and business associations were replacing declining traditional social networks based on clans and age sets/groups. Climate change, development agencies, cultural and technological change and neighbourhood social learning are perceived as having inspired the innovations. Innovations that fragmented natural and social capital were inclined to limit socio-ecological resilience. Implementation of new interventions among communities must factor in the possibilities of transformation and/or emergence of new innovations beyond those initially conceptualised as implementation progresses. Supportive policies that recognise the increasing complexity of common property use are needed to address emerging 'new' land use changes. Furthermore, there is need to nurture emergent promising innovations and stop those considered detrimental to the sustainability of SESs.
\end{abstract}

Keywords: Group ranches, Innovations, Laikipia, Pastoralists, Socio-ecological system, Resilience

\section{Background}

Pastoralism in Eastern Africa has faced many challenges in recent decades, including an increase in climate variability and subsequent effects on forage and water availability, the declining authority of traditional institutions that effectively managed range resources in the past (Bekure et al. 1991; Sundstrom et al. 2012), reduced

\footnotetext{
*Correspondence: staline@uonbi.ac.ke; kibets3k@gmail.com 'Department of Land Resource Management and Agricultural Technology, University of Nairobi, P. O. Box 29052, 00625 Nairobi, Kenya Full list of author information is available at the end of the article
}

access to grazing land attributable to changes in tenure systems and other policies (Thornton et al. 2006), as well as the increase in human population (Bekure et al. 1991; Kiteme et al. 1998). The devastating drought events of 1969 , the 1970 s and the 1980 s, with significant reliance on international food aid, together with the initiation of range development trials increased the vulnerability of pastoral communities (Oba 1994). Experiments with range development projects such as range enclosures, block grazing, group ranches, range improvement and rehabilitation were implemented across the Eastern 
African rangelands with the goal of building or restoring the resilience of ecosystems. At the same time, alternative economies to pastoralism that involved sedentarisation (for example, dryland farming, irrigated agriculture and fisheries) were also introduced, often with minimal success (Oba 1994). The establishment of group ranches (GRs) seems to have received more attention than other policies. There is an extensive literature on the establishment of GRs, pointing out some of the inherent problems of the model as well as challenges to their implementation (Coldham 1982; Galaty 1994; Kimani et al. 1998; Bekure et al. 1991; Ngethe 1992; Peacock 1987).

In the last decade, several studies have focused on impacts of the subdivision of GRs to plots held under individual freehold tenure. Such impacts may be on wildlife (Wayumba et al. 2006; Western et al. 2009), on the livelihood of agro-pastoral households (Burnsilver and Mwangi 2007; Thornton et al. 2006), on livestock populations (Boone et al. 2005) and on social capital and traditional management systems (Sundstrom et al. 2012). A recent development in the transformation of GRs has been the establishment of grazing associations, in which friends or neighbours agree to graze their privatelyowned land jointly, with the aim of increasing livestock mobility and thus avoiding land degradation from yearround grazing (Burnsilver and Mwangi 2007). Significant amounts of research have been done on Maasai GRs, but most of these studies focused largely on the southern Kenya rangelands, particularly those in Kajiado and Narok Counties. Fewer studies have been done on the Laikipia Maasai GRs (Hauck 2013). Despite the underlying similarity of objectives and circumstances among most GRs at their establishment, since then, the southern and northern rangeland GRs have differed in their evolutionary paths. One notable divergence between them is the increased individualisation of operations in southern GRs, compared to the retention of fairly collective actions in the north. At the time of writing, the northern GRs have yet to subdivide their land into individual freehold parcels. In the recent past, nine GRs have 'consolidated' their land parcels for wildlife management and conservation under an umbrella body, the Naibunga Wildlife Conservancy. These efforts seemed to have paid off in view of the fact that the region has the second largest population of wildlife outside the protected areas of Kenya, with equally increasing livestock populations (Kinnaird et al. 2012; Ngene et al. 2013; WRI et al. 2007).

The central thesis in this study is that group-ranchlevel-driven and/or collective action-based innovations in the management of livelihood assets are more socio-ecologically resilient in comparison with household/ individual-driven innovations. Despite receiving a number of significant negative forces, including the loss of large areas of grazing land through the 1904 and 1911 treaties imposed by the colonial government (Keen 1962), the land fragmentation that accompanied the GR policy and broader forces associated with increased globalisation, the socio-ecological systems of the Laikipia Maasai have survived fairly well.

Socio-ecological system (SES) in this context is used to refer to a GR made up of nature (e.g. water, pastures) and humans (e.g. their beliefs and practices), as well as combined human-nature systems that are shown in coevolved systems of management (adopted from Holling 2001). The capacity of these SESs to absorb disturbance and re-organise while undergoing change but still retain essentially the same function, structure and feedbacks indicates some level of resilience of the fundamental livelihood assets. Livelihood assets are people's strengths (capital endowments) that can be converted into livelihood outcomes (DFID 1999). They may be tangible (e.g. trees and land) or intangible (e.g. access to education and information). Nurturing and combining a range of these assets (such as natural, financial, human, social or physical) in innovative ways enables people to achieve positive livelihood outcomes.

Livelihood diversification and land use change in the arid and semi-arid lands of Eastern Africa (including Laikipia) have been the subject of many studies (Campbell et al. 2003; Olson et al. 2004; Galvin 2009; Desta and Coppock 2004; Jillo et al. 2006). Different concepts have been put forward as inspiring livelihood diversification in arid and semi-arid regions. Among the Turkana, for example, impacts of drought, increasing insecurity and famine has forced sedentarisation of once pure nomadic and semi-nomadic pastoralists to explore alternative livelihoods (Watson and Binsbergen 2008). There are examples of movement to non-pastoral livelihoods such as tourism, petty trades, fishing, wage employment and cultivation. Alongside the livelihood diversification debate is the aspect of climate change and its impact on pastoral livelihood. Some scholars perceive pastoralists as vulnerable to climate change while others view them as the most capable to adapt to climate change, since pastoral livelihoods are shaped to deal with scarce and variable natural resources (Nori and Davies 2007).

This study aimed at understanding innovative pathways in the management of pastoral livelihood assets among the GRs in Laikipia County. Il Motiok GR was used as a case study to investigate the unpredicted 'innovations' in the management of natural and social capital. Key questions that were addressed included the following: What are emergent innovations in GR management of natural and social capital at both household and larger community levels among the Laikipia Maasai?; What drives the innovations?; and What are 
the perceived and felt impacts of the innovations on the resilience of the SES?

\section{Conceptual framework}

All traditional resource management systems are under constant change in response to stress, hazards, risks or opportunities and can be said to be in a form of adaptive cycle (Berkes et al. 2000; Walker et al. 2004). This study contends that in the absence of colonial and postcolonial intervention, the Laikipia Maasai (like other pastoralists) would have continued with their constant change in managing their livelihood assets in response to the uncertainty and unpredictability of their ecosystems due largely to climate dynamics. It is hypothesised that the creation of GRs and the accompanying policies altered the trajectory and probably also the rate of that change. Innovations in the management of natural and social capital and resultant resiliency are perceived as a function of climatic variables (e.g. rainfall frequency and amounts), government policy directives and the social learning gained from neighbours and other sources. Other less direct drivers may include prevailing economic trends (market trends) and population dynamics (unprecedented increase in population), as well as advances in science and technology (e.g. mobile phone technology), all of which have combined with other forces to cause significant cultural change (Figure 1).

It is also hypothesised that strategies adopted a range from the household level (micro-system) to the level of the extended community (landscape). A previous study has shown that the level of vulnerability of households to climatic, economic and other shocks and the range of options they can access to address such shocks differ between wealthier and poorer households because of their capital endowment (Hauck 2013). It is, however, too early to predict future sustainability of the emerging innovations, but it is possible to speculate on their potential long-term effect on the resilience of SES. The term 'resilience' is used to mean the capacity of an SES to sustain a desired set of ecosystem services in the face of disturbance and ongoing evolution and change (Biggs et al. 2012). The assumptions in this conceptual framework are that no external inputs get into the system and that no one among the population is transiting out of the pastoral production system.

\section{Study site}

Laikipia County lies between latitudes $0^{\circ} 18^{\prime \prime}$ south and $0^{\circ} 51^{\prime \prime}$ north and between longitudes $36^{\circ} 11^{\prime \prime}$ and $37^{\circ} 24^{\prime}$ east. It covers an area of $9,462 \mathrm{~km}^{2}$. Il Motiok GR is one of the 11 GRs in the region, lying in the northernmost part of the county. The GR covers an area of 3,651 ha and borders Mpala and Soita Nyiro private ranches to the west, Koija GR to the north, Tie Mamut GR to the east and Mukogodo private ranch to the south (Figure 2). The elevation ranges from 1,550 to $1,700 \mathrm{~m}$, with gentle undulating terrain. The ranch lies between two major drainage lines, Ewaso Nyiro River (permanent) and Losupukiai (seasonal river). The two drainage lines largely influence the use of the ranch with wet season grazing occurring towards Losupukiai and dry season zones towards Ewaso Nyiro River side because of access to permanent water.

Il Motiok GR lies on the Laikipia Plateau, a classical savanna ecosystem with a mosaic of clay, sandy and transitional soils. The county is rich in large savanna mammals such as elephants, giraffes, buffaloes, zebra and several species of carnivores among others. Among the endangered fauna in this county are half of Kenya's black rhino population, two thirds of the world population of Grevy zebras and the world's sixth largest population of wild dogs (Boy 2011). The vegetation of the area is wooded savanna dominated by several species of acacia.

The County has a variety of land tenure and land use types. The biggest area of land ( $>50 \%$ of County land area) is categorised as large-scale ranching and farms. They are owned by individuals, companies and state or government parastatals. A sizeable area was previously

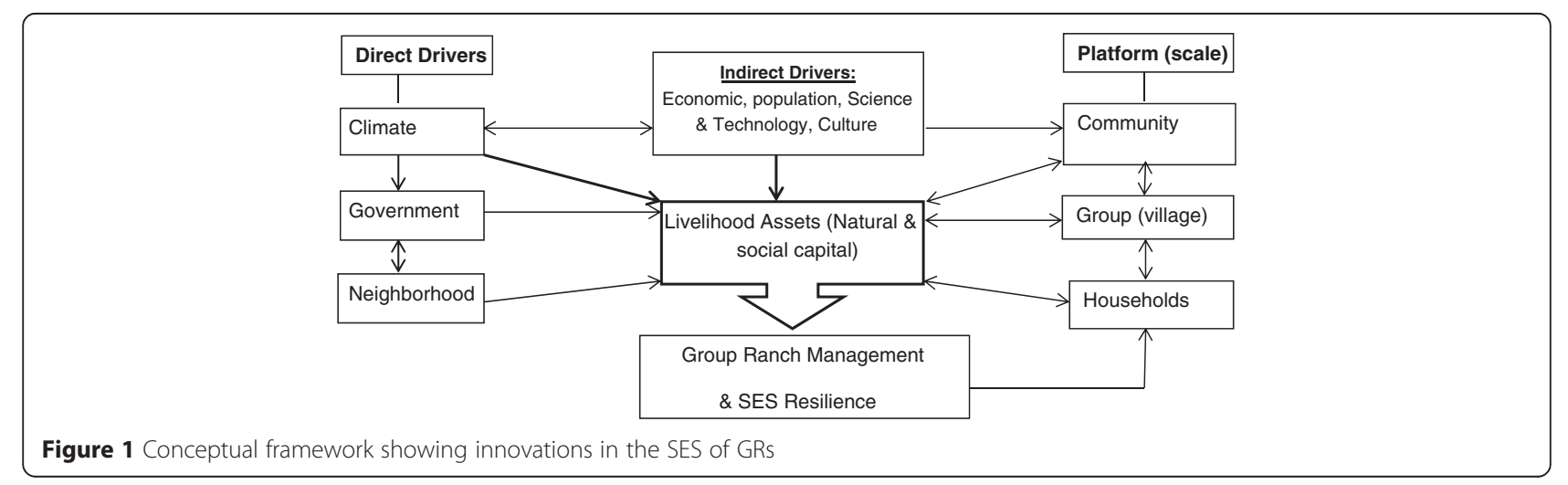




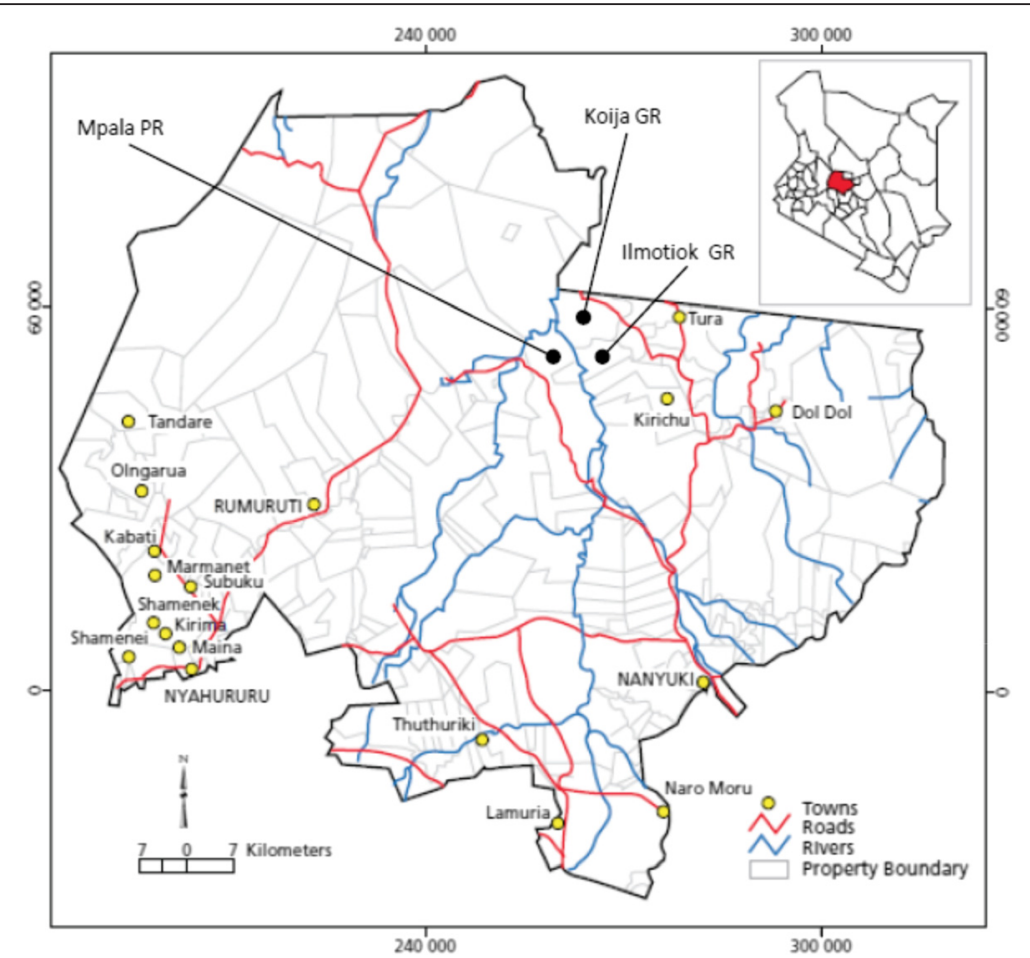

Figure 2 Map showing location of Laikipia County and the study site. Background details indicate land properties. Map adopted from Ojwang et al. 2010

held under a 999-year lease which was later revised to 99 years (Kenya Constitution 2010). Common land use types under this category include commercial livestock production, a combination of livestock production and wildlife conservation, and pure wildlife conservation (Conservancies). Small but expanding land use types in the County are the small-holder farms. These include parcels of land awarded during government resettlement programmes following Kenya's independence in 1963 together with privately acquired lands. They are mainly found in the south and south-western parts of the County, and their dominant forms of land use are crop cultivation and agro-pastoralism. Pastoralism is yet another category, practised on land held under communal ownership with livestock production as the main economic activity. Communal group ranches that are the focus of this study fall within the pastoralism land use category. Laikipia County also contains government forests, wetlands and rapidly growing urban settlements (Kiteme et al. 1998).

The study site has about 110 households with approximately 1,000 inhabitants (Kaye-zwiebel and King 2014) spread across four villages, namely Nasirian, Lorupai, Losiagi and Il Motiok. The community keeps cattle, sheep, goats and donkeys and most recently has adopted camels and poultry. The livestock stocking rates vary greatly following seasonal fluctuations that dictate availability of pastures and water. In the recent past, active wildlife conservation has been introduced.

\section{Methods}

This study was conducted between April 2012 and March 2014. The data collected included emerging innovations in natural and social capital, factors motivating these innovations and felt and/or perceived impacts of the new strategies on sustainability of pastoral livelihood. Natural capital was considered to include pastures, wildlife, livestock, minerals and vegetation while social capital included networks, gifting, reciprocity, employment, education and wage remittance by relatives. Both primary and secondary data were used in this study. Strategies used to collect primary data included semistructure questionnaires, key informant interviews (KIIs), focus group discussions (FGDs) and participants' direct observations through transect walks and photography.

Both KIIs and FGDs purposely targeted men and women older than 40 years who had consistently lived in the area for more than 25 years, in order to benefit from their long-term experience. KIIs were carried out both in Il Motiok and the Mpala private ranch (PR). The Mpala ranch has had long-term collaboration with Il Motiok, and a number of its employees are residents of the ranch. Key informants included GR management committee officials, self-help groups' leaders, experienced 
herders and elders and those in wage employment. In Mpala, the management and long-serving staff were targeted. Twenty-six KIIs were undertaken, six in Mpala ranch and the rest in Il Motiok GR. Eight FGDs, two in each village, were held in which four to six people participated. Separate FGDs were held for both genders to avoid male dominance in the discussions. Interviews and FGDs were held in the local Maa language with assistance from one woman and three young men, all fluent in both English and Maa languages. A total of 105 face-to-face interviews were carried out (targeting both men and women) making up $10.5 \%$ of the total GR population. Fifty-two percent of the interviewees were women and the rest were men.

To appreciate household-driven initiatives and how those initiatives differed with the level of wealth, two households, one 'relatively rich' household (with 35 tropical livestock unit (TLU)) and one relatively poor household (with 7 TLU), were selected. This poverty ranking was based on a household economy assessment undertaken in North East Turkana, Kenya (Levine and Crosskey 2006). In this assessment, they observed that for a pastoral family to be able to feed its members and survive drought, each adult needs 6 TLUs. ( 1 TLU is equivalent to $250-\mathrm{kg}$ animal live weight; 1 camel $=1$ TLU; 1 cattle $=0.7 \mathrm{TLU}$; 1 sheep $/$ goat $=0.1 \mathrm{TLU}$, as per FAO (1986)). Using second order cybernetics, the two households were observed for one season. Second order cybernetics is a tool not based on determining the facts on the ground but on observing the observer. For a second-order observation, the question is not "What is there?' but 'How does the observer construct what he constructs?' It asks the question 'What are the distinctions that are used by the observed-observer?' (see Kaufmann 2007). In the context of this study, we aimed at isolating information derived by the observer (household head) by observing 'signals' transmitted by trait carriers (livestock or environmental attributes) that interested him (those 'signals' that made meaning to him). Observing animals' behaviours, or range conditions, send 'signals' about declining or improving quality and/ or quantity of pastures and the need for the observer to take certain actions. This was done mainly through observing and recording the observer's daily decisions and actions.

Photography and transect walks guided by a community person were also done. Five Google Earth maps (Image@ 2014 DigitalGlobe) for 2007 to 2013 were used to observe land use changes and also to estimate the increase of land under cultivation and traditional enclosures locally known as olokerii. The data was qualitatively analysed by coding recurring concepts and frequencies calculated using SPSS software version 15.0 (SPSS Inc. 1989 to 2006).

\section{Results}

The key innovations observed among the Laikipia Maasai are provided in Table 1 . Some of the innovations were either household-level-driven initiatives or at the group ranch level and commissioned by elected officials. Natural and social capital innovations have been addressed separately although they are discussed jointly in the next section because of their interconnectedness. It should be noted that some of the innovations may not be entirely attributed to GR formation but to other broader aspects of development such as globalisation of economies, advancement in science and cultural dynamics, among others.

\section{Innovations in natural capital resource use}

Two broad categories of natural resource management strategies linked to the GR model were observed, pasture swap and use diversification.

\section{Pasture swap}

Pasture is a critical resource, and because of the uncertainty and unpredictability of the ecosystems in which they operate, pastoral communities go exceptional lengths to manage it. Two types of pasture swaps were recorded, namely; 'cooperation' between private ranches (PRs) and GRs and trading in pastures or pasture leasing.

Private-GR pasture alliances emerged in the early 2000s out of simmering tensions between pastoralists and large-scale ranch owners over access to pastures during dry seasons. To promote cohesion, PRs agreed to permit pastoral groups access to pastures during times of forage scarcity, subject to meeting some conditions. Below are some of the conditions set by the Mpala private ranch:

(i) Livestock owners meet the costs of ecto-parasite control for their animals as well as for hired herder(s) while grazing in Mpala. In 2013 and 2014, the rate was Kshs 150 (approx. US\$ 1.5) per head of cattle per month.

(ii) Each GR allowed access must organise to have all their cattle herded jointly for ease of controlling grazing pattern, thus the need for a hired herder in (i) above. GRs nominated person(s) to be hired to herd their livestock.

(iii) Only cattle were allowed admission and sheep only under special situations. Goats were not permitted at all due to the perception that they degrade the rangeland.

(iv) Each PR set the maximum number of cattle to be admitted at any given time to avoid overgrazing. For example, Mpala ranch allowed a maximum of 800 cattle at any given time, principally from Il Motiok, Koija and Tie Mamut GRs. 
Table 1 Emergent innovations in the management of natural and social capital among group ranch pastoral communities in Laikipia, Kenya

\begin{tabular}{|c|c|c|c|c|}
\hline \multicolumn{2}{|l|}{ Livelihood assets } & \multirow{2}{*}{$\begin{array}{l}\text { Emergent innovation } \\
\text { Trading grazing rights to non-members (agistment) }\end{array}$} & \multirow{2}{*}{$\begin{array}{l}\text { Citations }(n=105) \\
42\end{array}$} & \multirow{2}{*}{$\frac{\text { Percent frequency }}{40}$} \\
\hline Natural capital & Pasture swap & & & \\
\hline & & Private ranch - GR alliance & 38 & 36 \\
\hline & & Expansion of Olokerii enclosures ${ }^{\mathrm{a}}$ & & \\
\hline & Resource use Diversification & Sand mining & 63 & 60 \\
\hline & & Wildlife and tourism & 38 & 36 \\
\hline & & Cultivation & 29 & 28 \\
\hline & & Manure sale & 19 & 18 \\
\hline & & Charcoal making & 17 & $16^{\mathrm{b}}$ \\
\hline & & Buying and selling of livestock & 82 & 78 \\
\hline & & Rearing of camels & 13 & 12 \\
\hline & & Increasing small stock (sheep and goats) & 84 & 80 \\
\hline & & Rearing of poultry & 23 & 22 \\
\hline \multirow[t]{6}{*}{ Social capital } & Human & Children formal schooling & 82 & 78 \\
\hline & & Hiring of Scouts/Rangers & 32 & 30 \\
\hline & & Wage remittance by salaried relatives & 19 & 18 \\
\hline & Networks & Associations and self-help groups & 48 & 46 \\
\hline & Businesses/trade & Eco-tourism related & 13 & 12 \\
\hline & & Others & 29 & 28 \\
\hline
\end{tabular}

${ }^{a}$ Olokerii enclosures were not part of citations but a critical observation made during field surveys

${ }^{b}$ Charcoal making was officially banned in the GR in 2009

Trading grazing rights (pasture leasing/agistment) Trading grazing rights to non-members of the GRs (mostly Somali camel herders) was yet another land use innovation that began in 2001. The Somali herders purchased grazing rights to fatten their camels before selling or during times of forage scarcity. The payment rate for grazing one camel per month in 2013 was Kshs 300 (approx. US\$ 3.4). Between March and August 2013, there were 170 camels in the ranch (Godffrey Metiaki, 2013, GR Chairman, pers. communication).

Expansion of Olokerii enclosures Expansion in structure and function of traditional enclosures (Olokerii) was observed through transect walks as well as using satellite maps. Between 2007 and 2013, the enclosures increased by $38 \%$ from 26 to 36 and their average size per enclosure tripled from approximately 0.4 to 1.3 ha..

\section{Diversification in natural resource use}

Besides livestock production, the community has been experimenting with new livelihood options, using resources available but has hardly been exploited in the past. Some of these include the following:

Charcoal making Between 2001 and 2009, the Il Motiok community experimented with the charcoalmaking business but then abandoned it. This was cited by $16 \%$ of the informants, who said they had participated in the business as charcoal makers, buyers, sellers or brokers. This was a group-ranch-level decision and was sanctioned by the management committee on behalf of the community.

Crop cultivation Crop cultivation in Il Motiok GR began in 2007. In the last seven years (to the end of 2013), the land under cultivation increased from about 3.24 ha. to approximately 12.14 ha.. Crop cultivation was concentrated along the Ewaso Nyiro River, and in 2014, more than $20 \%$ of the households were involved. The majority of those involved in cultivation were people aged below 45 years with at least basic primary education. In a household that had cultivation field, both men and women were involved in the farm activities. In the five years that cultivation has taken place on the ranch, successful harvests have been reaped only twice due to limited rainfall, so it is hard to understand why individuals continue with this activity.

Harnessing tourism potential To benefit from the potential of tourism, GRs have been encouraged to set aside a portion of their land as wildlife conservancies. Nine GRs have set aside part of their land for the purpose of promoting wildlife conservation and tourism. In Il Motiok, a 10th of its land was set aside for wildlife 
conservation, and a women's group has established an eco-lodge facility for tourists, with help from a donor agency. Thirty-six percent of the informants cited tourism as a major source of income for the GR and households involved in businesses related to tourism (e.g. supply of food and beadworks).

Mining of sand and stones Sand and stone mining started in Il Motiok GR in the year 2000. These activities occur along flood plains and dry riverbeds (locally referred to as luggas). Sixty percent of the informants cited sand mining as a major income earner for the GR. In 2014, 7 tonnes of sand was worth Kshs 4,000 (approx. US\$ 45) and employed two local persons for loading and paid Ksh 400 each for labour. Sand harvesting and selling was a group-ranch-level initiative, and those directly involved were mainly young men.

\section{Change in species composition, breeds and trade in livestock}

The change in the composition of livestock species owned by households, and the significance of each species in meeting family requirements, showed a major shift in livestock production. More than $80 \%$ of the respondents indicated that they have increased the number of small stock (goats and sheep) relative to cattle which was the main livestock species historically. A livestock census done on the ranch in 2010 shortly after a severe drought tallied the following: cattle 207, shoats 3197 , camels 20 and poultry 651 . Twelve percent of the households have introduced camels, while $22 \%$ of households have introduced poultry. Less than $5 \%$ of households have introduced new breeds of goats and sheep, primarily Galla and Dorper, respectively.

\section{Trade in livestock manure}

Only $19 \%$ of our informants mentioned manure sale as supplementing their household income, although, in our home visits, we observed that most if not all households collect and preserve manure for sale. The value of a lorry full of manure was Kshs 10,000 (approx. US\$ 115, 2014 rate).

\section{Dynamics in management of social capital}

The sedentarisation of households was an inevitable outcome of the establishment of GRs. One reason is that the land for nomadic pastoralism was heavily constricted by the establishment of boundaries. Secondly, the creation of permanent infrastructure such as water sources (e.g. dams) and schools made household mobility less appealing. Members of Il Motiok GR settled in four villages (Nasirian, Lorupai, Losiagi and Il Motiok). Community members were free to choose where to settle in any of the villages. Historically, the Maasai settled in a group of kraal camps that tends to gather around a dry season water supply. Such a group was locally known as enkutoto, a 'settlement association', and was a fairly stable political unit with its own governance structures (Coldham, 1982).

Increased reliance on purchased goods and services from the marketplace by households has limited gifting and sharing to special occasions such as weddings and circumcisions.

\section{The existence of scouts/rangers}

Scouts/rangers were a new institution established to address challenges such as cattle raids, poaching of wildlife and enforcement of grazing protocols. The local youth (men only) were recruited and trained with help from the Northern Rangeland Trusts (an NGO operating in the region) to scout for signs of security breach and on how to use modern technologies such as high-frequency radios and binoculars, among others skills. The rangers were paid by the GRs through the Naibunga Wildlife Conservancy Trust.

\section{New social networks}

New social networks requiring members to join more formalised groups governed by mutually agreed or commonly accepted rules, norms, by-laws and sanctions were observed. Examples are the Nalepo women's selfhelp group (that managed the Ol Gaboli Eco-lodge) and a beekeepers' association.

\section{Wage remittance}

About $20 \%$ of respondents cited employment as the critical source of their household income. Among 11 persons interviewed on wage employment, only one was a woman. Most of those employed were within the neighbouring private ranches and occasionally visit the family within the month.

\section{Religion}

Although not cited by many as playing any role in the re-organisation of social capital, it featured during the FGD session as influencing the future life of the community. The Christian converts in the area believed that Christianity will instil new values as well as provide solutions to societal problems such as low literacy level among women, poverty, cattle raids and female genital mutilation among others. As of 2014, two churches had been constructed in the ranch. The extent of Christianity among the population was beyond the scope of this study.

\section{Discussion}

The GR as a model for managing rangeland resources has evolved over time and has given birth to new 
innovations, some of which are far from the path envisaged at its conception. Some of the emergent approaches in the management of natural and social capital assets were modifications of previously existing strategies; others were completely new ones. Household-driven initiatives may have evolved as part of a wider diversification of livelihood strategies. They were individualised in their nature and their benefits accrued to individual households. Innovations implemented at the community level were collective actions and mean to provide common good to GR members. Operationalisation of these innovations was confined by GR boundaries. Notable among them were the trading of grazing rights, ecotourism, charcoal making and sand mining.

Vulnerabilities (stresses) attributed to climate variability and changes, as well as trends such as government policies, markets, social learning and overall changing lifestyles, could have inspired some of the current innovations. Initiatives that brought immediate benefits such as sand mining, eco-tourism and trading of grazing rights were popular even though their long-term sustainability was unknown.

\section{Pasture swap}

The establishment of PRs during the colonial period and GRs in post-independent Kenya fragmented pastoral grazing land. Access to heterogeneity of landscapes is an important attribute of the pastoral grazing landscape, and therefore, land fragmentation limits options for people and animals to access resources in a temporally and spatially heterogeneous environment (Hobbs et al. 2008). Dry season grazing areas, access routes to water and migration routes were among other utilities were disrupted by the GR model, thus jeopardising the flexibility needed in the utilisation of drylands. This was, however, not unique to Laikipia Maasai. What is unique here is how the GR model has survived for four decades while a number in the southern rangelands barely lasted 10 years (Veit 2011). The pasture-use cooperation (alliance) between PRs and GRs is one innovation that has given a lifeline to Laikipia GRs. Traditionally, pastoral communities in Africa and elsewhere practised reciprocity with neighbouring communities, under which pastures were shared during hard times (Fernandez-Gimenez 2000; Eriksen and Lind 2009). Partnership with private ranches is fairly new. The persistent and frequent scarcity of forage on the GRs compared to their neighbouring PRs had been a source of tensions in Laikipia. During the droughts of the 1990s and 2000s, pastoral groups in the county, out of desperation and as a result of political machinations, trespassed into PRs. This provocative action, instead of ending up in the courts, led to a negotiated grazing agreement between the two parties. Besides easing tensions, the need for enhanced collaboration in areas of wildlife conservation and security in the region informed this strategy.

A notable impact of the pasture-use alliance between PRs and GRs was increased collaboration in the area of security, wildlife conservation and promotion of ecotourism through the Laikipia Wildlife Forum and Naibunga Wildlife Conservancy. This agreement provided a window for increased livestock mobility, an opportunity for vegetation to regenerate and connectivity of people and habitats, which is an essential element in range resilience (Biggs et al. 2012). Furthermore, the conditional joint herding proposed under negotiated grazing agreements between PR and GRs has promoted cohesion among members of the GR. The members have to come together when making a decision concerning their livestock-herding strategies. These attributes promote SES resilience through collective actions (Coppock and Desta 2013).

\section{Trading of grazing rights (agistments)}

Trading of grazing rights or agistments as referred to by Robert and Mcallister (2010) involves allowing nonmembers of a ranch to graze their livestock at a fee. This was one of the community-level initiatives and was directly linked to GR status as knowledge of ranch boundaries by lessee was essential to avoid conflicts with neighbours. The motivation for leasing land to nonmembers (particularly Somali camel herders) was economic benefits. The money earned makes it possible for the GR to support education for members' children as well as improve social amenities (e.g. buying of desks in schools). Declining grass resource and perceived encroachment by woody plants on the ranch could have also inspired the undertaking to increase browsing as a control measure. Unlike the non-pastoralists currently viewed as a threat to Maasai pastoral livelihoods in Kajiado and Narok (Sundstrom et al. 2012), camel herders in Laikipia have in the immediate past created some form of symbiotic relationship, which is addressed later in this paper. Unfortunately, the GR did not have means to estimate sustainable stocking rate to avoid potential land degradation and possible conflicts as have been reported from other parts of Kenya (see http://www.the-star.co.ke/news/2014/ 04/15/herders-and-ranchers-clash-in-taita-taveta_c925582, http://www.hiiraan.ca/news4/2014/Nov/77135/kenya_maasai_group_wants_somali_herders_out.aspx). Trading in grazing rights has not only provided income but also promoted social capital; there has been some transformation of relationships by which existing collaboration has fostered establishment of new relationships.

\section{Olokerii enclosures}

These 'privately owned' enclosures were traditionally used for nursing sick animals, as a postpartum recovery 
wing for livestock and nursery for young calves and kids or restraining newly acquired livestock (Kibet and Oyieke 2009). It is not clear whether there was an accepted size of olokerii; however, the majority was less than 10.4 ha. Olokerii was 'owned' by individual households, and therefore, access by non-household members was through permission. The structure and functions of these enclosures have, however, been transforming over time. Alongside the traditional use, olokerii are currently used as a dry season grazing reserve, a strategy driven by individual household desires.

Motivations for the expansion of olokerii enclosures were varied. Decline in availability of household labour, increased individualisation of pastoral operations, decline in number of livestock to sustain mobility and increased sedentarisation are some of the factors. Notable impacts of olokerii expansion were the upsurge in tree felling for fencing and maintenance, a decline in area of land under common use thus increasing grazing pressure on plants in 'open access' areas and the expansion of invasive species (Opuntia subalata) previously used as a live fence on these enclosures. Although fencing has not reduced available habitat, it has limited connectivity and access to micro-habitats such as floodplains known to host more diverse plant species. On a positive note, plant species susceptible to heavy grazing were likely to get refuge in the enclosures and minimise potential local extinction as observed in Ethiopia (Mengistu et al. 2005). Habitat fragmentation and limited connectivity depresses SES resilience.

Cultivation Cultivation along the Ewaso Nyiro River was one of the household-based emergent strategies aimed at diversifying livelihood options. Influence from NGOs operating in the area as well as neighbours (such as Koija GR where cultivation begun earlier) may have triggered the emergence of crop production in Il Motiok GR. Cultivation, like charcoal making, is a new type of land use. Shifting cultivation as well as fencing reduces riverine forest cover and, more importantly, destroys dry season grazing pastures. Similar to olokerii enclosures, this may heighten tensions and/or conflicts due to possible trespasses. This was likely to increase herding labour in future, weaken community cohesion and increase agitation for land subdivision into freehold as noted elsewhere in the country (Mwangi 2005; Sundstrom et al. 2012). A study by Kaye-zwiebel and King (2014) on five GRs in the region, noted on four of the ranches (Koija GR was the exception), that the majority of individuals surveyed did not favour land subdivision into individual titles. This was a surprising observation given that the Koija community appears to have the strongest social assets (in terms of food sharing, livestock lending and sanctioning) necessary for maintaining a resilient communally-based pastoral livelihood. Increased 'individualisation' of land through cultivation could have motivated this position. Between 2007 and 2014, there was an increase of over $200 \%$ in the area under cultivation, and homesteads built near cultivated fields increased from one to eight. Increased cultivation is also likely to escalate water stress downstream. Studies on natural flow on the major rivers in the region indicate a gradual decline over the years due to increased upstream abstractions for irrigated agriculture with increasing conflicts between farmers upstream and pastoral communities downstream (Mungai et al. 2004; Ngigi 2006). Presence of large population of wildlife in the region (WRI et al. 2007) and widespread crop raiding by elephants within small-scale cultivated farms in Southern Laikipia (Graham 2006) are warnings of escalating future confrontations. Moreover, cultivation in itself is inconsistent with the earlier investments in wildlife conservancy and a tourist facility (eco-lodge). Livestock trespassing into crop fields was also inevitable, and this would strain the relationship between neighbours. Experience from other regions indicates that cultivation in fragile ecosystem, such as Il Motiok, compromises habitat connectivity andspecies diversity, and may also strain communities' cohesiveness between those with crop fields and those more interested in livestock well-being (Galvin 2009; Sundstrom et al. 2012; Biggs et al. 2012).

Charcoal Charcoal making initially commenced as a measure to control bush encroachment on the ranch. Perceived increase in the density of trees on the ranch was seen as posing risks of wildlife attacks due to declining visibility, particularly from elephants. Felling of woody plants along access paths was therefore commissioned by GR officials for the purpose of improving the safety of residents, particularly school-going children. It was also seen as an opportunity to generate income from charcoal sale. Charcoal making was initially spearheaded by non-Maasai; however, through social interaction, members of the ranch community acquired the skills and got involved in the business. As more people participated in the business, guidelines set earlier were flouted. Tree felling went far beyond the designated areas. After eight years of wanton felling of trees, targeting most valuable forage species such as Acacia tortilis and Acacia mellifera, it became evident that the practice was not sustainable and it was officially stopped. The high number of livestock lost as an aftermath of the 2009/2010 severe drought may have informed the decision. Selective harvesting of certain species of acacia threatened both forages for livestock, especially the browsers (e.g. goats and camels), and weakened the ecological insurance (functional redundancy and response diversity) that the harvested species provide during extreme weather events 
(Walker et al. 2004; Kahmen et al. 2005). Recognising that SESs are complex adaptive systems presupposes that experimentation and learning are necessary for societal learning and enhanced resilience (Biggs et al. 2012). Valuable lessons derived from the charcoal-making experiment are that active adaptive management still forms part of this GR's management style (Fazey et al. 2005) and that collective action can be an effective means of group problem solving (Coppock and Desta 2013).

\section{Sand and stone mining}

Increasing sedentarisation and expanding urban centres in the region caused increased demand for building sands. With the establishment of county governments in the country, there has been unprecedented growth of urban centres, and Nanyuki town is recognised as a major consumer of building sand from the GRs in the region. Sand mining is fairly recent in Il Motiok compared to the neighbouring GRs of Il Polei and Tie Mamut. This activity was motivated by the need to raise income, and like charcoal making, the business was commissioned as a GR initiative. The community seemed highly excited about sand harvesting given the high percentage of those who support it. Although sand mining is currently minimal, it is affecting critical habitats - the floodplains and dry riverbeds (locally called luggas). These sites provide important ecosystem services such as soil erosion regulations, provision of water, dry season grazing pastures, habitat for wildlife and cultural values. These services will be compromised in the long term. Some of the already-felt impacts from sand mining include increased erosion along the paths used by heavy lorries ferrying sand as exemplified by deep gullies and frequently changing pathways on the ranch and emergence of conflicts between members of neighbouring GRs over ownership of sand resources on shared boundaries and also within GR members competing for sand-loading jobs. For example, in 2013, elders of Tie Mamut and Il Motiok had to agree on a formula to share income and jobs from the sand on their shared boundary (Losupukiai lugga) after hostilities occurred. The spread of invasive species is a potential threat, given the large distances covered by lorries ferrying the sand. This study therefore foresees that increased sand mining will cause loss of dry season grazing areas, and decline in community cohesion between neighbours, which together with enhanced soil erosion are all likely to increase vulnerability to environmental shocks, thus weakening SES resilience.

Changes in herd composition, species and breeds Traditionally, cattle formed the dominant herd in the Maasai households relative to sheep and goats (jointly shoats), but this was seen to be changing. The acquisition of new breeds of goats and sheep was associated with wealthier households. The following reasons were cited by the community for increase adoption of camels and shoats (i) Both camels and goats have higher tolerance to water and forage shortages (ii) Goats: ease of acquiring breeding stock and faster multiplication rate after losses, and availability of ready market (iii) Camels: continue to produce milk even during dry season when most lactating livestock dry up.

The Il Motiok community as landlord relied heavily on camel milk supplied by their Somali tenants during and shortly after the severe drought of 2009/2010 as most of their livestock were either dry or had been driven to graze out of the ranch. This experience could have influenced the rising adoption of camels. The role of camel milk as a source of food and family income is likely to rise with increase in climate variability (Elhadi et al. 2015). Increased trade in livestock, facilitated by proximity to two markets (Kimanjo and Oldo Ng'iro) where livestock is the main trade commodity, will influence livestock dynamics in the future. Acquisition of new species and adoption of new breeds increase diversity at the species and genetic level, respectively. This enhances SES resilience by increasing diversity response as well as functional redundancy against adverse events such as drought (Biggs et al. 2012).

Re-organisation of social and human capital Following sedentarisation of pastoral households, settlement villages replaced traditional inkutot (settlement associations) as the smallest formal political segment of the Maasai (Coldham 1982). The established villages became the smallest units of GR administration, since officials are elected based on these units. The new institution imposed by the GR policy replaced the traditional institutions where natural resources were managed by a council of elders. Based on observations made during the study and information from informants, the Il Motiok GR committee have largely been effective in their 'foreign policy', which can be exemplified by dealings that involve non-members, such as negotiating grazing agreements and employment opportunities for their members with the adjacent large private ranches and leasing agreements with charcoal makers and sand merchants. However, enforcement of internal regulations addressing natural resource use was facing challenges. Social sanctions play an important role in the provision of public good (Miguel and Gugerty 2004), and effective administration of social sanctions demonstrates the capacity of a community for self-governance. Weakness in enforcing rules governing natural resources was noted to vary, with some ranches in the region seen as more effective than others (Kaye-zwiebel and King 2014). Grazing protocols and expansion enclosures (olokerii and crop 
fields) were not being regulated by the GR committee officials on Il Motiok ranch and were blamed by community members although effective management demands collective action by all members.

Herding is crucial in the debate about sustainability of pastoral livelihood because of the centrality of livestock mobility in the production system (Butt 2011; Coppolillo 2000; Oba 1994). In the past, herding among the Maasai community was a shared activity among relatives, friends and/or neighbours (Bekure et al. 1991). This has changed with decline in number of livestock, increased individualisation of production and labour shortage. Additionally, government policies that encourage schooling of children and sedentarisation by pastoral communities are transforming livestock management and society in general. Most children (both boys and girls) of school-going age attend school, and livestock herding is carried out either by hired person(s) for rich households or by adult women in poorer households. Shortage of herding labour is reflected in the violations of grazing protocols in Il Motiok GR as women would combine herding and other household chores by grazing livestock near homes. During this study, some GRs were experimenting with joint herding with the help of PRs and a local NGO. Hired labour was used to regulate grazing inside PRs as well as within the GR where Holistic Management experimental trials had been initiated. Although its full potential was yet unknown, some households were already excited about the strategy.

The importance of traditional social networks among the Il Motiok community seemed to be breaking down as exemplified by increased income inequality among households and insignificant gifting or exchanges between rich and poor (Hauck 2013; see also Kaye-zwiebel and King 2014, Bekure et al. 1991). New social networks have emerged to boost dwindling social capital. Some of these networks are beekeepers and beadwork associations for negotiating better prices for goods and services. Table banking where women save and loan money to members was taking over gifting/reciprocity as a way to support the recovery of people who had lost their livelihood. Emergence of these networks to promote collective action was not unique to Il Motiok GR and was seen to fortify social and human capital (Coppock and Desta 2013) and thus enhance SES resilience.

Another important observation with social reorganisation among the Il Motiok community was the social barriers surmounted by adoption of innovation. The majority of the married women in the community did not participate in off-ranch employment. However, the formation of home-based economic activities (e.g. Ol Gaboli Eco-lodge) for tourists offered women opportunities to work as cooks, cleaners or waiters without restrictions from their husbands. In addition, women make beaded jewellery, weave mats, supply foodstuff and even get paid to entertain tourists through songs and dance.

A number of policy implications can be drawn from this study. Whereas it is a well-established fact that livestock mobility is central in promoting sustainable pastoralism from accessing spatially and temporally heterogeneous resources, not much is being done to achieve the same. Increasing complexity of land use types in previously dominant pastoral land suggests the need for responsive policy change to ensure that fragile ecosystems are not overly exposed to irreversible degradation. There are opportunities provided by community-tocommunity social learning to adapt to unpredictable and uncertain environment, and positive elements derived from such knowledge should be recognised and if necessary promoted. Policy initiatives therefore should seek to address these issues as well as develop means to promote collective actions.

\section{Conclusions}

It is evident from the results that the GR model has shown unpredictable innovation pathways in the management of natural and social assets not envisaged at its inception. These innovations consist of both new and modified forms of traditionally known practices, some of which were household- and/or community-level-driven processes. There are many factors that may have influenced the emergence of new innovations; climate change, development agents (e.g. government, NGOs) and social learning from neighbours as part of a wider change in lifestyle are likely to have been some of the important ones. People interviewed on the ranch were mostly positive about innovations that were seen as bringing in immediate tangible benefits/income (e.g. sand mining, manure sale, crop cultivation). However, they did not often show awareness that the potential long-term effects on socio-ecological system resilience could be negative. Official abandoning of charcoal making as a diversification strategy after it had been in operation for five years indicates that adaptive learning still dictates the management strategies that the community adopts.

It is indicative from this study that interventions such as the GR model evolve in space and time, and we suggest that flexibility both in funding and policies is needed to allow unintended or unpredicted innovations to emerge as implementation progresses. The increasing complexity of common property use requires responsive policies to address emerging 'new' land use changes (e.g. tourism, cultivation, sand mining and others) in previously purely pastoral grazing land. Equally important would be to initiate/strengthen policies that would promote collective action. In Kenya, policies such as the 
Youth Development Fund where a prerequisite for government support is the formation of a formal cohesive group can be customised to suit pastoral communities and encourage collective action. Similarly, it is imperative that pastoral land remain as common property, given that further fragmentation is considered detrimental to socio-ecological system sustainability.

\section{Acknowledgements}

This study was partially supported by FOREST-GEO grants and Centre for Sustainable Drylands Ecosystems and Societies. We thank Godffrey Metiaki (then Chairman of II Motiok group ranch) for allowing the team to undertake research in their ranch. We appreciate the work done by field assistants, Agnes Keshine, Daniel Metiaki, Nicholas Kipsuny, Jacob, Peter and Timothy Metiaki, in data collections and language interpretation. Celia Nyamweru edited the manuscript for which we are thankful. The Mpala Research Centre supported logistics for which we are grateful. Lastly, we acknowledge the anonymous reviewers for their comments for it greatly improved the quality of the manuscript.

\section{Authors' contributions}

SK, MMN, LM and DK designed the research; SK carried out data collection and data analysis and wrote the manuscript while MNN, LM and DK provided technical guidance on methodology, data synthesis and editing of the manuscript. All authors read and approved the final manuscript.

\section{Competing interests}

The authors declare that they have no competing interests.

\section{Author details}

${ }^{1}$ Department of Land Resource Management and Agricultural Technology, University of Nairobi, P. O. Box 29052, 00625 Nairobi, Kenya. ${ }^{2}$ CTFS-ForestGEO, Smithsonian Tropical Research Institute, NMNH West loading dock, 10th \& Constitution Ave. NW, Washington 20560-0188, USA.

Received: 24 November 2015 Accepted: 6 July 2016

Published online: 31 August 2016

\section{References}

Bekure, S., P.D.D. Leeuw, B. Grandin, and P. Neate. 1991. The Maasai: Socialhistorical context and group ranches. In Maasai herding: An analysis of the livestock production system of Maasai pastoralists in eastern Kajiado District, Kenya, ed. S. Bekure, P. de Leeuw, B.E. Grandin, and N. PJ. PJ. Addis Ababa: International Livestock Research Institute.

Berkes, F., J. Colding, and C. Folke. 2000. Rediscovery of traditional ecological knowledge as adaptive management. Ecological Applications 10(5): 1251-1262.

Biggs, R., M. Schlüter, D. Biggs, E.L. Bohensky, S. BurnSilver, G. Cundill, and P.C. West. 2012. Toward principles for enhancing the resilience of ecosystem services. Annual Review of Environment and Resources 37(1): 421-448.

Boone, R. B., Burnsilver, S. B., Thornton, P. K., Worden, J. S., and Galvin, K. 2005. AQuantifying Declines in Livestock Due to Land Subdivision. Rangeland Ecology \& Management 58: 523-532.

Boy, G. 2011. Laikipia - a natural history guide. Nanyuki, Kenya: Laikipia Wildlife Forum publication

Burnsilver, S., and E. Mwangi. 2007. Beyond group ranch subdivision: Collective action for livestock mobility, ecological viability, and livelihoods, (No. 66). DC: Washington

Butt, B. 2011. Coping with uncertainty and variability: The influence of protected areas on pastoral herding strategies in East Africa. Human Ecology 39(3): 289-307.

DFID (DEPARTMENT FOR INTERNATIONAL DEVELOPMENT) (1999) Sustainable Livelihoods Guidance Sheets. Overseas Development Institute, UK

Campbell, D. J, Gichohi, H., Mwangi, A., Smucker, T. 2003. Globalization and Local Heterogeneity: An Overview of Diversity in Land Use and Development Issues in Loitokitok Division, Kajiado District, Kenya. Land Use Change Impacts and Dynamics (LUCID) Project. Working Paper 21.Nairobi, Kenya: International Livestock Research Institute.

Coldham, S. 1982. The registration of group ranches among the Maasai of Kenya - some legal problems. Journal of Legal Pluralism 20: 1-16.
Coppock, D.L., and S. Desta. 2013. Collective action, innovation, and wealth generation among settled pastoral women in Northern Kenya. Range Ecology and Management 66: 95-105.

Coppolillo, P. B. 2000. The Landscape Ecology of Pastoral Herding: Spatia Analysis of Land Use and Livestock Production in East Africa. Human Ecology, vol. 28(4): 527-560

Desta, S., and D.L. Coppock. 2004. Pastoralism under pressure: Tracking system change in Southern Ethiopia. Human Ecology 32(4): 465-486.

Elhadi, Y.A., D.M. Nyariki, and O.V. Wasonga. 2015. Role of camel milk in pastoral livelihoods in Kenya: Contribution to household diet and income, 5(8). Pastoralism: Research, Policy and Practice.

Eriksen, S., and J. Lind. 2009. Adaptation as a political process: Adjusting to drought and conflict in Kenya's drylands. Environmental Management 43(5): 817-35.

FAO. 1986. Production yearbook 1985: No. 39.. Rome: FAO.

Fazey, I., J.A. Fazey, and D.M.A. Fazey. 2005. Learning more effectively from experience. Ecology and Society 10(2): 4.

Fernandez-Gimenez, M.E. 2000. The role of Mongolian nomadic pastoralists' ecological knowledge in rangeland management. Ecological Applications 10(5): 1318-1326

Galaty, J. 1994. Having land in common: the subdivision of maasai group ranches in Kenya. Nomadic Peoples, Number 34/35: 109-122.

Galvin, K.A. 2009. Transitions: Pastoralists living with change. Annual Review of Anthropology 38(1): 185-198.

Graham, M. 2006. Coexistence in a land use mosaic? Land use, risk and elephant ecology in Laikipia District. Cambridge: Kenya.

Government of Kenya, 2010. Kenya Constitution. Government Printers, Nairobi.

Hauck, S. 2013. Pastoralist societies in flux: The impact of ecology, markets, and governmental assistance on the Mukugodo Maasai of Kenya. Unpublished PhD Dissertation submitted to Department of Ecology and Evolutionary Biology. USA: Princeton University.

Hobbs, N.T., K.A. Galvin, C.J. Stokes, J.M. Lackett, A.J. Ashd, R.B. Boone, R. Robin, and P.K. Thornton. 2008. Fragmentation of rangelands: Implications for humans, animals, and landscapes. Global Environmental Change 18(4): 776-785.

Holling, C.S. 2001. Understanding complexity of economic, ecological, and social systems. Ecosystems 4(5): 390-405.

Jillo, A., A.A. Aboud, and D.L. Coppock. 2006. From herd diversification to livelihood diversification as a response to poverty: The case of the Waso Boran of Northern Kenya (No. 06-05 PARIMA).. Davis, USA.

Kahmen, A.. J. Perner, and N. Buchmann. 2005. Diversity-dependent productivity in semi-natural grasslands following climate perturbations. Functional Ecology 19: $594-601$

Kaufmann, B. 2007. Cybernetic Analysis of Socio-biological Systems: The Case of Livestock Management in Resource-Poor Environments. Margraf Publishers GmbH, Scientific books, 2007 Kanalstraße 21; D-97990 Weikersheim.

Kaye-zwiebel, E., and E. King. 2014. Kenyan pastoralist societies in transition: Varying perceptions of the value of ecosystem services. Ecology and Society 19(3): 17.

Keen, J. (1962) Memorandum on Masai Treaties of 1904 and 1911. Presented at the Kenya Constitutional Conference, Lancaster House, 23 March, 1962

Kibet, S. and Oyieke, H. 2009. Possible integration of traditional knowledge, gender roles and beliefs in modern conservation. A commissioned study for Research Programme on Sustainable Use of Dryland Biodiversity (RPSUD), National Museums of Kenya, Nairobi.

Kimani, K. and Pickard, J. 1998. Recent trends and implications of Group Ranch sub-division and fragmentation in Kajiado District, Kenya. The Geographical Journal, vol. 162(2):202-213.

Kinnaird, M., T. O'Brien, and G. Ojwang. 2012. Sample count aerial surveys as a monitoring tool for wildlife and livestock: A case study from Laikipia County, Report submitted to Laikipia Wildlife Forum, Nanyuki, Kenya.

Kiteme, B P., Wiesmann, U., Kúnzi, E., and Mathuva, J M. 1998. A HighlandLowland System under Transitional Pressure: A Spatio-Temporal Analysis. Eastern and Southern Journal of Geography vol. 8 Special number, September 1998.

Levine, S., and A. Crosskey. 2006. Household economy assessment of North East Turkana.

Mengistu, T., D. Teketay, H. Hulten, and Y. Yemshaw. 2005. The role of enclosures in the recovery of woody vegetation in degraded dryland hillsides of central and northern Ethiopia. Journal of Arid Environments 60(2): 259-281.

Miguel, E., and M.K. Gugerty. 2004. Ethnic diversity, social sanctions, and public goods in Kenya. 
Mungai, D. N., Ong, C. K., Kiteme, B., Elkaduwa, W., Sakthivadivel, R. 2004. Lessons from two longterm hydrological studies in Kenya and Sri Lanka. Agriculture, Ecosystems and Environment vol. 104: 135-143

Mwangi, E. 2005. The transformation of property rights in Kenya's Maasailand: triggers and motivations. CAPRi Working Paper No. 35. International Food Policy Research Institute 2033 K Street, N.W. Washington, D.C. 20006 U.S.A.

Ngene, S., J. Mukeka, F. Ihwagi, J. Mathenge, A. Wandera, G. Anyona, T. Nyumba, L. Kawira, I. Muthuku, J. Kathiwa, P. Gacheru, Z. Davidson, J. King, and P. Omondi. 2013. Total aerial count of elephants, Grevy's zebra and other large mammals in Laikipia-Samburu-Marsabit ecosystem in (November 2012). Nairobi: Shadrack Ngene.

Ng'ethe, J.C. 1992. Group ranch concept and practice in Kenya with special emphasis on Kajiado District. In Kategile J. A. and Mubi S. eds); Future of livestock industries in East and southern Africa. Proceedings of a workshop held at Kadoma Ranch Hotel, Zimbabwe, 20-23 July 1992. ILCA (International Livestock Centre for Africa), Addis Ababa, Ethiopia. 227 pp.

Ngigi, S.N. 2006. Hydrological impacts of land use changes on water resources management and socio-economic development of upper Ewaso Ng'iro river basin in Kenya.. PhD Dissertation, Delft University of Technology.

Nori, M., and J. Davies. 2007. Change of wind or wind of change? Climate change, adaptation and pastoralism. The World Initiative for Sustainable Pastoralism (WISP). Nairobi: IUCN.

Oba, G. 1994. The role of indigenous range management knowledge for desertification control in northern Kenya, 1-38. Uppsala, Sweden.

Ojwang', G., Agatsiva, J. and Situma, C. 2010. Analysis of Climate Change and Variability Risks in the smallholder Sector; Case studies of the Laikipia and Narok Districts representing major agro-ecological zones in Kenya. FAO, Rome, Italy.

Olson, J.M., S. Misana, D.J. Campbell, M. Mbonile, and S. Mugisha. 2004. The spatial patterns and root causes of land use change in East Africa. (No. 47).

Peacock, C. 1987. Herd movement on a Maasai group ranch in relation to traditional organisation and livestock development. Agricultural Administration and Extension, vol 27(2): 61-74

Robert, R., and J. Mcallister. 2010. Livestock mobility in arid and semi-arid Australia: Escaping variability in space. Pastoralism 1(1): 37-54.

Sundstrom, S., J.F. Tynon, and D. Western. 2012. Rangeland privatization and the Maasai experience: Social capital and the implications for traditional resource management in Southern Kenya. Society and Natural Resources 25(5): 483-498.

Thornton, P.K., BurnSilver, S.B., Boone, R.B, and Galvin, K.A. 2006. Modelling the impacts of group ranch subdivision on agro-pastoral households in Kajiado, Kenya. Agricultural Systems 87: 331-356.

Veit, P. 2011. The rise and fall of group ranches in Kenya.. Focus on Land in Africa.

Walker, B., Holling, C. S., Carpenter, S. R., Kinzig, A. Resilience, Adaptability and Transformability in Social - ecological Systems. Ecology and Society, vol 9 (2) 5

Watson, Dj, and J. Van Binsbergen. 2008. Livelihood diversification opportunities for pastoralists in Turkana, Kenya, ILRI Research Report 5. ILRI (International Livestock Research Institute), Nairobi, Kenya, 43.

Western, D., Groom, R., Worden, J. 2009. The impact of subdivision and sedentarization of pastoral lands on wildlife in an African savanna ecosystem. Biological Conservation vol. 142(11): 2538-2546.

World Resources Institute; Department of Resource Surveys and Remote Sensing, Ministry of Environment and Natural Resources, Kenya; Central Bureau of Statistics, Ministry of Planning and National Development, Kenya; and International. Livestock Research Institute. 2007. Nature's benefits in Kenya. An atlas of ecosystems and human well-being. Washington, DC and Nairobi: World Resources Institute.

Wayumba, R. N. and Mwenda, J. N. 2006. The Impact of Changing Land Tenure and Land Use on Wildlife Migration within Group Ranches in Kenya: A Case Study of the Amboseli Ecosystem The Impact of Changing Land Tenure and Land Use on Wildlife Migration within Group Ranches in Kenya: A Case Study of the Amboseli Ecosystem. Promoting Land Administration and Good Governance 5th FIG Regional Conference Proceedings, Accra, Ghana 8-11th March 2006

\section{Submit your manuscript to a SpringerOpen ${ }^{\circ}$ journal and benefit from:}

- Convenient online submission

- Rigorous peer review

- Immediate publication on acceptance

- Open access: articles freely available online

- High visibility within the field

- Retaining the copyright to your article

Submit your next manuscript at $\gg$ springeropen.com 